Coordenação de Aperfeiçoamento de Pessoal de Nível Superior (CAPES), Conselho Nacional de Desenvovimento Científico e Tecnológico $(\mathrm{CNPq})$, and Fundação de Amparo à Pesquisa do Estado de Minas Gerais (FAPEMIG) provided financial support and scholarships.

Dr. Esteves is a veterinarian dedicated to native wildlife conservation. He is the leader of a nongovernmental agency dedicated to the rescue and rehabilitation of wild animals. On his farm, he maintains and cares for about 170 animals that are not fit to reintroduce into nature.

\section{References}

1. Tripathy DN, Reed WM. Pox. In: Saif YM, Barnes HJ, Glisson JR, Fadly AM, McDougald LR, Swayne DE, editors. Diseases of poultry. 11th ed. Ames (IA): Iowa State University Press; 2003. pp. 253-269.

2. Gyuranecz M, Foster JT, Dán Á, Ip HS, Egstad KF, Parker PG, et al. Worldwide phylogenetic relationship of avian poxviruses. J Virol. 2013;87:4938-51. http://dx.doi.org/10.1128/JVI.03183-12

3. Boosinger TR, Winterfield RW, Feldman DS, Dhillon AS. Psittacine pox virus: virus isolation and identification, transmission, and cross-challenge studies in parrots and chickens. Avian Dis. 1982;26:437-44. http://dx.doi.org/10.2307/1590119

4. Huw Lee L, Hwa Lee K. Application of the polymerase chain reaction for the diagnosis of fowl poxvirus infection. J Virol Methods. 1997;63:113-9. http://dx.doi.org/10.1016/S01660934(96)02119-2

5. Tamura K, Stecher G, Peterson D, Filipski A, Kumar S. MEGA6: Molecular Evolutionary Genetics Analysis version 6.0. Mol Biol Evol. 2013;30:2725-9. http://dx.doi.org/10.1093/molbev/mst197

6. Saitou N, Nei M. The neighbor-joining method: a new method for reconstructing phylogenetic trees. Mol Biol Evol. 1987;4:406-25.

7. Felsenstein J. Confidence limits on phylogenies: an approach using the bootstrap.Evolution. 1985;39:783-91. http://dx.doi.org/10.2307/2408678

8. Tamura K. Estimation of the number of nucleotide substitutions when there are strong transition-transversion and $\mathrm{G}+\mathrm{C}$-content biases. Mol Biol Evol. 1992;9:678-87.

9. Niemeyer C, Favero CM, Kolesnikovas CKM, Bhering RCC, Brandão P, Catão-Dias JL. Two different avipoxviruses associated with pox disease in Magellanic penguins (Spheniscus magellanicus) along the Brazilian coast. Avian Pathol. 2013;42:546-51. http://dx.doi.org/10.1080/03079457.2013.849794

Address for correspondence: Nelson R.S. Martins, Universidade Federal de Minas Gerais-Medicina Veterinária Preventiva, Avenida Antonio Carlos 6627, Belo Horizonte 31270-901, Brazil;

email:nrsmart@gmail.com

\title{
Chikungunya Fever in Traveler from Angola to Japan, 2016
}

\author{
Saho Takaya, Satoshi Kutsuna, Eri Nakayama, \\ Satoshi Taniguchi, Shigeru Tajima, \\ Yuichi Katanami, Kei Yamamoto, \\ Nozomi Takeshita, Kayoko Hayakawa, \\ Yasuyuki Kato, Shuzo Kanagawa, Norio Ohmagari
}

Author affiliations: National Center for Global Health and Medicine, Tokyo, Japan (S. Takaya, S. Kutsuna, Y. Katanami, K. Yamamoto, N. Takeshita, K. Hayakawa, Y. Kato, S. Kanagawa, N. Ohmagari); National Institute of Infectious Diseases, Tokyo (E. Nakayama, S. Taniguchi, S. Tajima)

DOI: http://dx.doi.org/10.3201/eid2301.161395

Simultaneous circulation of multiple arboviruses presents diagnostic challenges. In May 2016, chikungunya fever was diagnosed in a traveler from Angola to Japan. Travel history, incubation period, and phylogenetic analysis indicated probable infection acquisition in Angola, where a yellow fever outbreak is ongoing. Thus, local transmission of chikungunya virus probably also occurs in Angola.

Qimultaneous circulation of multiple arboviruses has been observed several times in many parts of the world. In 1970, Angola reported an outbreak of a dengue-like syndrome, which turned out to be a concurrent outbreak of yellow fever and chikungunya fever (1). On April 13, 2016, the World Health Organization declared a yellow fever outbreak in Angola. In response to the outbreak, a nationwide yellow fever vaccination campaign was initiated. As of July 29, 2016, a total of 3,818 confirmed and suspected cases were reported (2). In addition, on July 23, 2016, the World Health Organization was notified of a Rift Valley fever case in a man from China working in Luanda, the capital city of Angola, and started an investigation in Angola (3). We describe a case of chikungunya fever in a traveler from Angola to Japan.

In May 2016, a 21-year-old woman traveled to Tokyo, Japan, from her home in Luanda. She began to exhibit a high fever on the first day of her visit. On the second day, she sought care at the National Center for Global Health and Medicine (Tokyo). She had been previously healthy and had not traveled out of Luanda in the past 6 months. She claimed to have been vaccinated according to the national immunization plan, which included vaccination against yellow fever. At the first visit, she had high-grade fever $\left(40.7^{\circ} \mathrm{C}\right)$ without other signs. Her vital signs were otherwise stable, and physical examination revealed no 
abnormality. Complete blood count and biochemistry tests revealed only a slightly elevated C-reactive protein level $(1.55 \mathrm{mg} / \mathrm{dL})$. Results of rapid diagnostic testing for malaria and dengue, 3 consecutive thin blood smears, HIV screening, and blood culture for bacteria were all negative.

After hospitalization, her fever gradually subsided but remained above $38^{\circ} \mathrm{C}$. On the fifth day, bilateral axillary lymphadenopathy appeared. The lymph nodes were $\approx 2 \mathrm{~cm}$, painful, and nonfluctuant. Despite the high-grade fever and lymphadenopathy, her general condition improved, and she was discharged on the fifth day. Thereafter, she recovered quickly and returned safely to Luanda.

Although the patient was supposedly vaccinated against yellow fever virus, we performed real-time reverse transcription PCR for yellow fever virus, and the result was confirmed to be negative. Testing for other arboviruses was performed, and real-time reverse transcription PCR for chikungunya virus (CHIKV) showed a positive result. Therefore, the final diagnosis was chikungunya fever. We used phylogenetic analysis based on the nucleotide sequence of the E1 gene from the serum sample, the maximum-likelihood method with 1,000 bootstrap replicates, and MEGA 6.0 software (http://www.megasoftware.net). The sequence was $98 \%$ identical to that of a CHIKV strain isolated in the Central African Republic in 1987 (Figure). Considering travel history, incubation period, and phylogenetic analysis, the patient was probably infected with CHIKV while in Luanda.

CHIKV was first isolated in Tanzania in 1953 (4). After a few decades of absence in Africa, the virus caused a large outbreak in the Democratic Republic of the Congo in 2000 (5) and has subsequently been causing infection across the continent. Although the epidemiology of chikungunya fever is scarcely understood in Africa, an effort has been made to grasp the current burden of CHIKV in Africa. A study in Kenya found the rate of CHIKV IgG positivity among HIV-negative specimens to be $0.96 \%$ (6). A serologic study in southern Mozambique found that the rate of seroconversion or a $\geq 4$-fold titer rise of CHIKV IgG among patients with acute febrile illness was $4.3 \%$ (7). These studies suggest that the incidence of CHIKV infection in Africa may be higher than previously assumed. This discrepancy may be explained by lack of awareness, diagnostic tools, and surveillance systems. As of April 22, 2016, Angola was not recognized as a country with local CHIKV transmission (8). However, considering that Angola harbors Aedes aegypti mosquitoes, which are efficient CHIKV vectors, and that neighboring countries have documented local transmission of the virus, it is reasonable to speculate that local transmission also occurs in Angola.

Co-infection and co-distribution of multiple arboviruses (including dengue viruses, CHIKV, and yellow fever virus) are widely reported $(1,9,10)$. Although these viruses share a common vector, Aedes spp. mosquitoes, their interactions within mosquitoes and their effects on vector competence are unknown (9). Arboviruses cause similar clinical presentations, which makes diagnosis challenging without labor-intensive diagnostics, especially in outbreak settings. Because a yellow fever outbreak is ongoing in Angola, the diagnosis of other arboviral infections is needed for conducting appropriate clinical and public health interventions and precise surveillance.

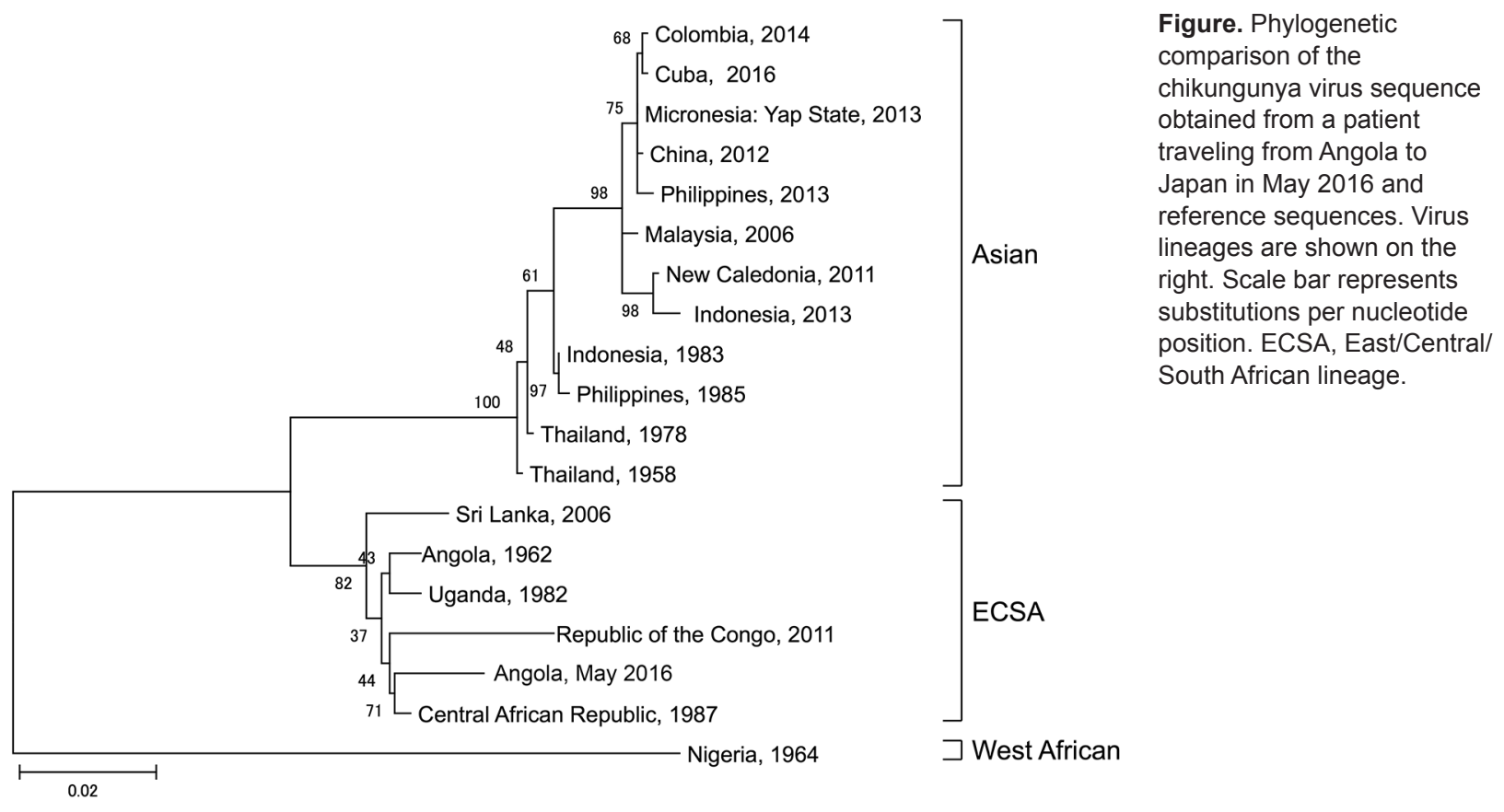


This case highlights 2 issues: the unknown epidemiology of CHIKV in Africa and the difficulty of diagnosing one arboviral infection during an outbreak of another arboviral infection. Further research is necessary to elucidate the true extent of CHIKV in African countries and to understand the public health implications of co-infection and co-distribution of multiple arboviruses.

This work was supported by a grant from the National Center for Global Health and Medicine (27-6001).

Dr. Takaya is a medical doctor at the National Center for Global Health and Medicine, Disease Control and Prevention Center. Her main research interest is tropical infectious diseases.

\section{References}

1. Filipe AF, Pinto MR. Arbovirus studies in Luanda, Angola. 2. Virological and serological studies during an outbreak of denguelike disease caused by the chikungunya virus. Bull World Health Organ. 1973;49:37-40.

2. World Health Organization. Situation report: yellow fever outbreak in Angola W30, 29 July 2016 [cited 2016 Aug 18]. http://www.afro.who.int/en/yellow-fever/sitreps/item/8866-situationreport-yellow-fever-outbreak-in-angola-29-july-2016.html

3. World Health Organization. Rift Valley fever in China [cited 2016 Aug 18]. http://www.who.int/csr/don/02-august-2016-rift-valleyfever-china/en/

4. Ross RW. The Newala epidemic. III. The virus: isolation, pathogenic properties and relationship to the epidemic. J Hyg (Lond). 1956;54:177-91. http://dx.doi.org/10.1017/ S0022172400044442

5. Moyen N, Thiberville SD, Pastorino B, Nougairede A, Thirion L, Mombouli JV, et al. First reported chikungunya fever outbreak in the republic of Congo, 2011. PLoS One. 2014;9:e115938. http://dx.doi.org/10.1371/journal.pone.0115938

6. Ochieng C, Ahenda P, Vittor AY, Nyoka R, Gikunju S, Wachira C, et al. Seroprevalence of infections with dengue, Rift Valley fever and chikungunya viruses in Kenya, 2007. PLoS One. 2015;10:e0132645. http://dx.doi.org/10.1371/journal.pone.0132645

7. Gudo ES, Pinto G, Vene S, Mandlaze A, Muianga AF, Cliff J, et al. Serological evidence of chikungunya virus among acute febrile patients in southern Mozambique. PLoS Negl Trop Dis. 2015;9:e0004146. http://dx.doi.org/10.1371/journal.pntd.0004146

8. Centers for Disease Control and Prevention. Geographic distribution. Where has chikungunya virus been found? [cited 2016 Aug 18]. https://www.cdc.gov/chikungunya/geo/index.html

9. Furuya-Kanamori L, Liang S, Milinovich G, Soares Magalhaes RJ, Clements $\mathrm{AC}, \mathrm{Hu} \mathrm{W}$, et al. Co-distribution and co-infection of chikungunya and dengue viruses. BMC Infect Dis. 2016;16:84. http://dx.doi.org/10.1186/s12879-016-1417-2

10. Parreira R, Centeno-Lima S, Lopes A, Portugal-Calisto D, Constantino A, Nina J. Dengue virus serotype 4 and chikungunya virus coinfection in a traveller returning from Luanda, Angola, January 2014. Euro Surveill. 2014;19:20730. http://dx.doi.org/10.2807/1560-7917.ES2014.19.10.20730

Address for correspondence: Satoshi Kutsuna or Saho Takaya, Disease Control and Prevention Center, National Center for Global Health and Medicine, 1-21-1, Toyama, Shinjuku, Tokyo 162-8655, Japan; email: sonare.since1192@gmail.com or takayasaho@gmail.com

\section{Puumala Virus in Bank Voles, Lithuania}

\author{
Petra Straková, Sandra Jagdmann, \\ Linas Balčiauskas, Laima Balčiauskienè, \\ Stephan Drewes, Rainer G. Ulrich
}

Author affiliations: Academy of Sciences, Brno, Czech Republic

(P. Straková); Masaryk University, Brno (P. Straková);

Friedrich-Loeffler-Institut, Greifswald-Insel Riems, Germany

(P. Straková, S. Jagdmann, S. Drewes, R.G. Ulrich); Nature

Research Centre, Vilnius, Lithuania (L. Balčiauskas,

L. Balčiauskienè)

DOI: http://dx.doi.org/10.3201/eid2301.161400

Little is known about the presence of human pathogenic Puumala virus (PUUV) in Lithuania. We detected this virus in bank voles (Myodes glareolus) in a region of this country in which previously PUUV-seropositive humans were identified. Our results are consistent with heterogeneous distributions of PUUV in other countries in Europe.

$\mathrm{P}$ uumala virus (PUUV) (family Bunyaviridae) is an enveloped hantavirus that contains a single-stranded trisegmented RNA genome of negative polarity (1). PUUV harbored by the bank vole (Myodes glareolus) is the most prevalent human pathogenic hantavirus in Europe (2). A high population density of bank voles can lead to disease clusters and possible outbreaks of nephropathia epidemica, a mild-to-moderate form of hantavirus disease (3).

In contrast to the Fennoscandian Peninsula and parts of central Europe $(4,5)$, little is known about the epidemiology of PUUV in Poland and the Baltic States. Recent investigations confirmed the presence of PUUV in certain parts of Poland $(5,6)$. A molecular study of bank voles in Latvia identified 2 PUUV lineages (Russian and Latvian) (7). In Estonia, serologic and molecular screening provided evidence of the Russian PUUV lineage (8). For Lithuania, a previous serosurvey indicated the presence of PUUVspecific antibodies in humans from 3 counties (online Technical Appendix Figure 1, http://wwwnc.cdc.gov/EID/ article/23/1/16-1400-Techapp1.pdf). However, molecular evidence of PUUV in humans or in voles is lacking (9).

We report a molecular survey of rodent populations in Lithuania at 5 trapping sites, including 2 sites in counties where PUUV-specific antibodies were previously detected in humans (online Technical Appendix Figure 1). A total of 134 bank voles, 72 striped field mice (Apodemus agrarius), and 59 yellow-necked field mice (A. flavicollis) were captured during 2015. Three trapping sites (Juodkrante, Elektrènai, and Lukštas) were located in forests at or near 